TESOL Quarterly invites commentary on current trends or practices in the TESOL profession. It also welcomes responses or rebuttals to any articles or remarks published here in The Forum or elsewhere in the Quarterly.

\title{
Multimodality in the TESOL Classroom: Exploring Visual-Verbal Synergy*
}

\section{TERRY ROYGE}

Teachers College, Columbia University Japan

Tokyo, Japan

- Communication through computer technology has increased the intermingling of text, audio, video, and images in meaning making to the point that Kress (2000) argues that it "is now impossible to make sense of texts, even of their linguistic parts alone, without having a clear idea of what these other features might be contributing to the meaning of a text" (p. 337). Elaborating on this assertion, Kress and van Leeuwen (1996) posit a comprehensive "grammar" of visual design and discuss the development of visual literacy and its educational implications. They juxtapose the rising importance of visual communication in the modern world with the traditional and continuing dominance of the verbal (i.e., linguistic) over the visual in educational systems. They also advance the view that, in spite of this revolution in communication modalities and priorities, there is a "staggering inability on all our parts to talk and think in any serious way about what is actually communicated by means of images and visual design" (p. 16). This statement is interesting given that Kress and van Leeuwen draw on a considerable body of research in such areas as communication and media studies (Dondis, 1973; Dyer, 1982; Fiske, 1982), the psychology of visual perception (Arnheim, 1969, 1974,

\footnotetext{
* This commentary is an extension of a presentation made at a colloquium on science discourse and education at the American Association of Applied Linguistics conference in Vancouver, British Columbia, Canada, in March 2000.
} 
1988; Gombrich, 1960), information design (Tufte, 1983) and visual semiotics (Barthes, 1967, 1977; Eco, 1976; Saint-Martin, 1987).

If making sense of (and constructing) texts requires the ability to understand the combined potential of various modes for making meaning, TESOL professionals need to be able to talk and think seriously about multimodal communication because they need to help learners develop multimodal communicative competence. Gaining a better understanding of multimodal communicative competence will entail a broad effort, but such an effort must include a means of analyzing the role of the image vis-à-vis language: Does it entice, decorate, or merely please? Does it perform a full communicational role in which it either reproduces language meanings, complements them, or realizes new meanings? These questions have been much discussed amongst semioticians (see Nöth, 1995, for a review), the most notable perhaps being Barthes (1977). Recent attempts to explain the co-occurrence of image and language in texts (see Royce, 1998, 1999a, 1999b, on intersemiotic complementarity in The Economist magazine) have identified a range of intersemiotic semantic mechanisms by which images and written language can work in concert on the page. This analytic approach offers insight into the semiotic interrelatedness of the two systems, and I therefore illustrate it here as a means for understanding one aspect of multimodal communicative competence.

In this commentary, I briefly illustrate the approach by analyzing a multimodal text extracted from an introductory environmental science textbook (Nielsen, Ford, \& Doherty, 1996). Besides demonstrating that while utilising the meaning-making features peculiar to their respective semiotic systems, the visual and verbal modes complement each other to realise an intersemiotically coherent multimodal text, I also suggest that the intersemiotic resources used to realise this complementarity can be readily explored for pedagogical purposes. As others (Halliday, 1994; Halliday \& Hasan, 1985; Kress \& Hodge, 1979; Kress \& van Leeuwen, 1996; O'Toole, 1994) have done, I draw on the social semiotic, metafunctional view of communication advanced by Halliday's (1994) systemic functional linguistics model, with a specific emphasis on the intersemiotic ideational meanings.

\section{ANALYSING MULTIMODAL TEXT}

High school science textbooks, like the textbooks used in many other subject areas, are filled with combinations of visual and verbal (or written) communication. Obviously, the authors and graphic designers place the various kinds of images, as well as the writing, on the pages not at random but for various semantic purposes. In Halliday's systemic functional linguistic model of communication, these purposes can be 
interpreted in terms of three metafunctions: the ideational metafunction (introducing informational content on certain subject matter), the interpersonal metafunction (involving various image acts and certain attitudes), and the textual metafunction (involving the organization of these features on the page in various ways and in accordance with accepted compositional or layout conventions).

The theoretical approach that I use for this analysis assumes that, although the visual and verbal semiotic systems utilize meaning-making resources in ways that are specific to their particular modes, they also collaborate to realise complementary intersemiotic meanings when they co-occur on the page or the computer screen. They work together to produce a coherent multimodal text for the viewers and readers, a text characterised by intersemiotic complementarity (Royce, 1999a, 1999b).

\section{MULTIMODAL SENSE RELATIONS}

The brief analysis here focuses on the ideational (experiential) meanings encoded in a multimodal text. It draws on and extends the concept of sense relations as outlined by Halliday (1994) and Halliday and Hasan $(1976,1985)$ in their discussions of lexical cohesion: repetition, synonymy, antonymy, meronymy (part-whole relations), hyponymy (class-subclass relations), and collocation. I attempt to demonstrate how meaning relations can occur across visual and verbal modes and to show that these relations can therefore be characterised as intersemiotic. For example, in a particular multimodal text both an image of some recognisable person and his or her name, designation, or label may appear in the verbal or written aspect. This co-occurrence can be interpreted as a reiteration or reinforcement of experiential meaning across modes, creating the sense that the same experiential meaning is represented in each mode. This might be described as intersemiotic repetition.

The aim of the intersemiotic ideational analysis presented here is to account for an object or person represented both visually (i.e., through visual representational techniques) and verbally (i.e., through semantically related lexical items) in a multimodal text. To analyze a typical multimodal classroom text, one could start with an image and examine its encoded ideational features by asking a series of questions, drawing on Halliday's (1994) functional categories of represented participant, process, circumstances, and attributes:

1. identification: Who or what are the represented participants, or who or what is in the visual frame (animate or inanimate)?

2. activity: What processes are there, or what action is taking place between the actor(s) and the recipient(s) or object(s) of that action? 
3. circumstances: What are the elements that are locative (i.e., concerned with the setting), are of accompaniment (i.e., participants not involved with the action), or are of means (i.e., participants used by the actors)?

4. attributes: What are the participants' qualities and characteristics?

The answers to these questions can produce descriptive glosses, referred to as the image's visual message elements (VMEs). The next step is to look at the writers' lexical choices to see how the visual ideational choices relate semantically to the verbal (written) ideational choices. The focus here is on the ideational intersemiotic sense relations mentioned above, which may constitute the multimodal mechanisms by which the visual and verbal modes can complement each other's experiential meanings.

The first of the sense relations explained above, intersemiotic repetition, involves the repetition of a lexical item that encodes the same experiential meaning encoded in the visual. The other sense relations that can be interpreted in this way are

- intersemiotic synonymy (similarity relations): The image of a scientist can be glossed as scientist, which may be intersemiotically synonymised by the lexical item researcher in the verbal aspect.

- intersemiotic antonymy (opposition relations): A graph showing increased degrees of temperature, glossed as increases over time, may be intersemiotically related through antonymy to the lexical item decreases.

- intersemiotic hyponymy (class-subclass relations): A sketch showing the various types of marsupials in desert areas, glossed as marsupials, may be intersemiotically related through hyponymy to the lexical item kangaroo (a type or subclass of marsupial).

- intersemiotic meronymy (part-whole relations): A schematic diagram showing an energy-efficient house, glossed as the meronym energyefficient house, may be intersemiotically related through meronymy to the lexical item solar panels (referring to specific parts of the energyefficient house).

- intersemiotic collocation (expectancy relations): A visual showing the effects of silting in harbours, glossed as silting, may collocate with the lexical item dredging (these words can be reasonably expected to cooccur in this topic area).

The following analysis illustrates how an examination and interpretation of a multimodal text in terms of its VMEs and associated lexical items can constitute a rich source of meanings with which to engage in the ESOL classroom. 


\section{THE WATER GYCLE TEXT}

The multimodal text analysed here, an extract from an environmental science textbook (Nielsen et al., 1996), deals with subject matter common to textbooks in general science and physical geography texts: the water cycle. The original text (see the Appendix) contains three sets of visuals-a drawing of the water cycle, a monochrome photo of a dam, and a series of six rainfall charts-but this analysis looks only at the water cycle drawing and specific aspects of the text's ideational features (see the Appendix).

By asking the identification question given above, one finds that the water cycle diagram reveals a range of VMEs both in terms of both the whole diagram and in terms of the individual participants represented within the visual frame. At the level of the whole figure (O'Toole, 1994) is the VME the water cycle (realised by the verbal heading and the sketched cyclical image), and at the level of individual represented participants are the VMEs land, ocean, clouds, moist air, water table, vegetation, and sun, which are realised by the verbal labeling and the line drawings of these shaped features (e.g., land, clouds, sun). In terms of the activity, at the level of individual represented processes are the VMEs precipitation, evaporation, transpiration, solar energy, infiltration, condensation, surface runoff, and groundwater runoff. These are realised not only through verbal labeling but also visually by the vectors created by the graphic arrows, which give direction as well as the sense that one participant is acting on or with another or that some action or process is taking place (e.g., solar energy acting on the ocean produces evaporation).

Taking the intersemiotic approach suggested above and using the identified VMEs as the starting point, one can examine the various sentences in the verbal aspect of the text to see how the visual experiential meaning of the whole figure, the water cycle, is related to the verbal experiential meanings. The results of this analysis can be expressed as an adaptation of lexical (cohesion) chain analysis (Table 1). In this approach, however, each lexical item is identified by moving back and forth from the visual to verbal, not from word to word through the text as in traditional cohesion analyses demonstrating lexical chaining. Almost every sentence in the verbal aspect of the text contains lexical items that relate semantically in some way to the water cycle VME. If this figure is seen as a whole, then the lexical items identified are largely meronyms to the superordinate whole figure (e.g., various lexical items, such as land, earth, water, rain, air, and plants, form lexically related parts of the visually represented water cycle). There is one instance of intersemiotic repetition in Sentence 9 , where water cycle is mentioned. Of interest here also is that, in a kind of voice print, the verbal aspect of the 
text speaks loudest on the visual topic, demonstrating degrees of the strength in intersemiotic complementarity.

I turn now to the individual represented VMEs in the water cycle diagram. A rich source of intersemiotic complementarity is associated with the VMEs land, ocean, clouds, moist air, water table, vegetation, and sun (conflating clouds and moist air). There are many instances of intersemiotic meronymy in the ocean $\mathrm{VME}$, which is the superordinate to the meronym water, and of collocation in the water table VME, in which such references as irrigation, salination, or seepage could be reasonably expected to cooccur in this topic area. There are scattered instances of hyponymy in the vegetation $\mathrm{VME}$, in which trees are a type of vegetation, and in the land VME, in which plains/flood plains are a type of land. There are scattered instances of repetition and some of synonymy, but none of antonymy.

Other analyses of the diagram might focus on the process VMEs represented-precipitation, evaporation, transpiration, solar energy, infiltration, condensation, surface runoff, and groundwater runoff-which also reveal various degrees of intersemiotic complementarity. In addition, the analysis here focuses only on the diagram, one of three sets of associated visuals in the text extract, and only in terms of the whole image and the represented participants. The other images (the photo and the six rainfall charts) could be the focus of another intersemiotic analysis,

TABLE 1

Intersemiotic Meanings for the Whole Figure

\begin{tabular}{|c|c|c|c|}
\hline Sentence & $\begin{array}{l}\text { Lexical item and } \\
\text { intersemiotic relation }\end{array}$ & Sentence & $\begin{array}{l}\text { Lexical item and } \\
\text { intersemiotic relation }\end{array}$ \\
\hline $1-3$ & - & 20 & plains (M) \\
\hline 4 & earth $(\mathrm{M})$ & 21 & cycle $(\mathrm{R})$, river $(\mathrm{M})$ \\
\hline 5 & land $(\mathrm{M})$; rain $(\mathrm{M})$ & 22 & land $(\mathrm{M})$ \\
\hline 6 & $\operatorname{air}(\mathrm{M})$ & 23 & water $(\mathrm{M})$ \\
\hline 7 & water (M) & 24 & water $(\mathrm{M})$ \\
\hline 8 & water $(\mathrm{M})$, air $(\mathrm{M})$ & 25 & trees $(\mathrm{M})$ \\
\hline 9 & water cycle $(R)$, earth $(M)$, water $(M)$ & 26 & plants $(\mathrm{M})$ \\
\hline 10 & rainfall $(\mathrm{M})$, rains $(\mathrm{M})$ & 27 & river $(\mathrm{M})$ \\
\hline 11 & $\operatorname{rainfall}(\mathrm{M})$ & 28 & underground water (M) \\
\hline 12 & water $(\mathrm{M})$ & 29 & $\begin{array}{l}\text { water }(M) \text {, seepage }(M) \text {, ground } \\
\text { water }(M)\end{array}$ \\
\hline 13 & water $(\mathrm{M})$; water $(\mathrm{M})$ & 30 & artesian water $(\mathrm{M})$ \\
\hline 14 & water $(\mathrm{M})$ & 31 & $\begin{array}{l}\text { marshes }(M) \text {, swamps }(M) \text {, water } \\
(M) \text {, water }(M) \text {, plants }(M)\end{array}$ \\
\hline 15 & water $(\mathrm{M})$, water $(\mathrm{M})$, rivers $(\mathrm{M})$ & 32 & water $(\mathrm{M})$; runoff $(\mathrm{M})$ \\
\hline 16 & water $(\mathrm{M})$, water $(\mathrm{M})$ & $33-35$ & - \\
\hline 17 & evaporation $(\mathrm{M})$ ) & 36 & water $(\mathrm{M})$, rivers $(\mathrm{M})$ \\
\hline 18 & - & 37 & water $(\mathrm{M})$, water $(\mathrm{M})$ \\
\hline 19 & flood plains (M) & 38 & \\
\hline
\end{tabular}

Note. $\mathrm{M}=$ meronymy; $\mathrm{R}$ = repetition. 
TABLE 2

Intersemiotic Meanings for the Represented Participants

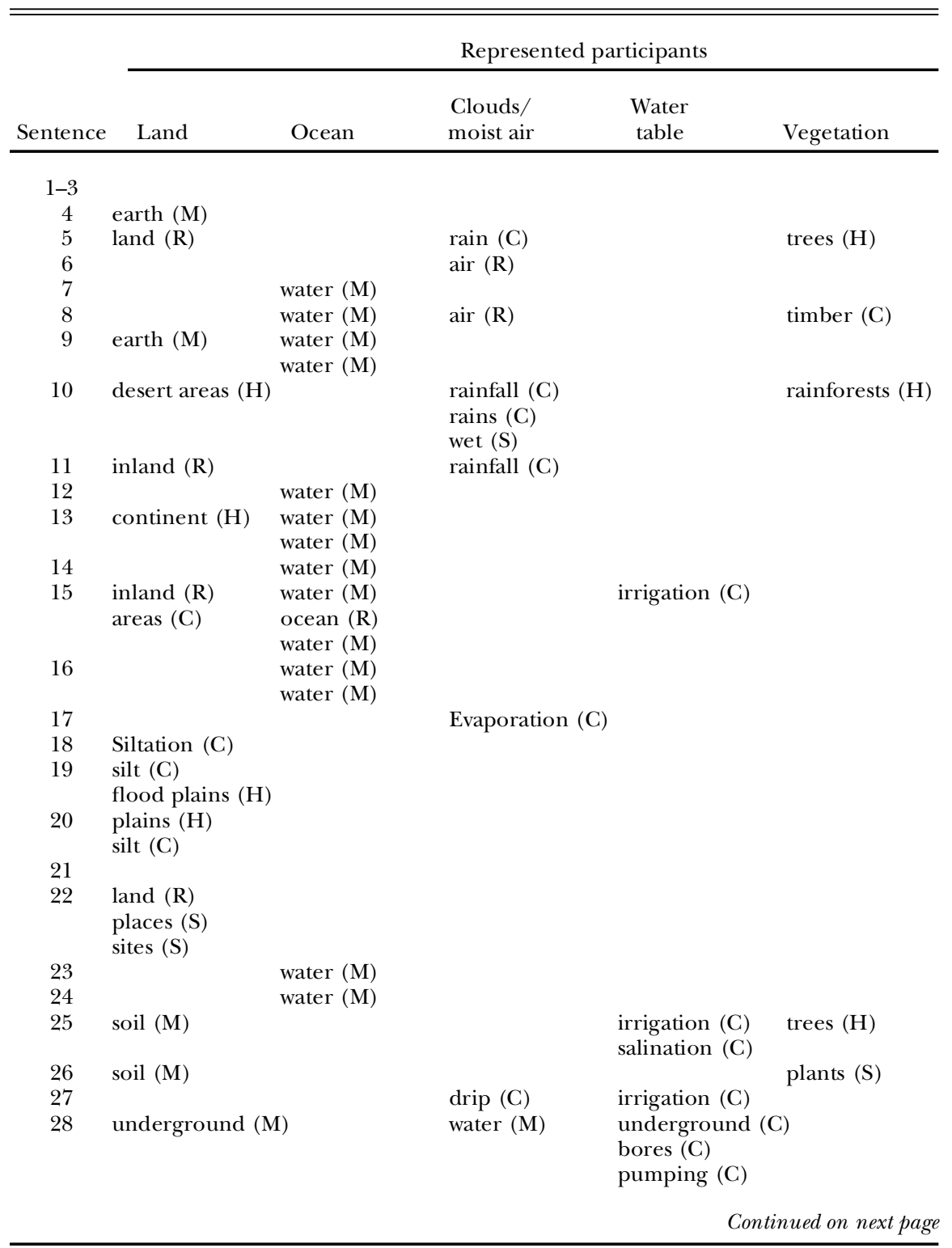

which might reveal that the visuals have not been placed on the page randomly but have been placed to work in concert with the verbal aspect to project a richly coherent multimodal text. 
TABLE 2, continued

Intersemiotic Meanings for the Represented Participants

Represented participants

\begin{tabular}{|c|c|c|c|c|c|}
\hline Sentence & Land & Ocean & $\begin{array}{l}\text { Clouds/ } \\
\text { moist air }\end{array}$ & $\begin{array}{l}\text { Water } \\
\text { table }\end{array}$ & Vegetation \\
\hline \multirow[t]{2}{*}{29} & \multirow[t]{5}{*}{ ground (S) } & \multirow{2}{*}{\multicolumn{2}{|c|}{$\begin{array}{l}\text { water }(\mathrm{M}) \\
\text { water }(\mathrm{M})\end{array}$}} & \multirow{2}{*}{\multicolumn{2}{|c|}{ seepage $(\mathrm{C})$}} \\
\hline & & & & & ground water (R) \\
\hline 30 & & \multicolumn{2}{|l|}{ water (M) } & \multicolumn{2}{|c|}{ artesian water $(\mathrm{R})$} \\
\hline \multirow{2}{*}{31} & & water (M) & & marshes $(\mathrm{C})$ & plants (S) \\
\hline & & water $(\mathrm{M})$ & & swamps (C) & \\
\hline 32 & & water $(\mathrm{M})$ & & runoff $(\mathrm{C})$ & \\
\hline 33 & & & & discharge $(\mathrm{C})$ & \\
\hline 34 & & aquatic $(\mathrm{C})$ & & & \\
\hline 35 & \multirow{4}{*}{ inland $(\mathrm{R})$} & & & & \\
\hline 36 & & water $(\mathrm{M})$ & & & \\
\hline 37 & & water $(\mathrm{M})$ & & & \\
\hline & & water $(\mathrm{M})$ & & & \\
\hline 38 & & & & & \\
\hline
\end{tabular}

Note. $\mathrm{C}=$ collocation, $\mathrm{H}$ = hyponymy, $\mathrm{M}=$ meronymy; $\mathrm{R}=$ repetition, $\mathrm{S}=$ synonymy.

\section{METHODOLOGIES FOR ENGAGING WITH MULTIMODALITY}

How can TESOL professionals explore with their students the copresence of visual, linguistic, and other modes in the textbooks, teaching resources, and computer screens they use in their classrooms to help learners develop multimodal communicative competence? I do not suggest that students carry out semiotic interrelatedness analyses in the classroom; any such analysis would need to be adapted for the students and evaluated in terms of its pedagogical efficacy in specific contexts. Nevertheless, because almost every image can be analysed in terms of what it presents, whom it is presenting to, and how it is presenting, the Hallidayan concept of metafunctions suggests ways for the ESOL teacher to develop pedagogical resources targeted to help students extract what visuals are trying to say and relate these messages to the linguistic aspect of the meaning. Some methodological suggestions arising from this approach follow.

\section{Reading}

Students might ask questions about visuals and use the answers to assist in their reading development. The richest source of information would be questions about the ideational aspects of a visual. Because many school subjects involve information, its organisation, and its 
relationship to other information, many classroom activities could centre on extracting what information the visuals are intended to convey to the viewers. The water cycle diagram, for example, is a typical expository visual that can be used in developing skills for reading science textbooks. The VMEs derived from asking these questions of a visual could then become the focus of further reading, writing, and speaking activities (and, indirectly, listening activities).

In developing reading readiness, for example, asking these kinds of questions about visuals can activate the students' background knowledge and thus reduce so-called text shock. By using the image to get some idea of what to expect, students can ease themselves into a reading. The process of reading the text then either confirms their expectations or, in rare cases, introduces areas of ambiguity between what they derive from the visual and what they read. The class can then explore these areas in more depth through discussion and written follow-up activities.

Activities based on multimodality can enhance students' understanding of a plot when they read narrative genres. For example, if a short story includes a sequence of visuals, as is common in many graded readers and abridged versions of novels used in schools, the students could look only at the visuals in sequence and try to figure out who the actors are, what they are doing, and why they are doing so. Before reading the story, the students could write what they think the actual story is and explain or discuss why. This kind of activity can help develop students' understanding of story and narrative structures: The image sequences and the writing activities arising from them could be used to introduce the students to other genres (e.g., description), with a focus on how visuals are organised. In expository writing development, an expository visual like the water cycle diagram could be used to explicate the way the cycle operates, as the visual tells a story, in a sense. The students could tell the story of the water cycle, with the sun (solar energy) as a starting point, for example. The story could serve as a basis for changing the writing to a more commonly used scientific form of writing, thus showing the students the differences between narrative and expository writing.

\section{Writing}

A closely related area for activities involving multimodality is writing development, especially narrative writing. Using a sequence of pictures extracted from a required reading, students could construct their own story individually or in groups and write the story in class, in a journal, or as the basis for a class magazine. The story writing or magazine production could become a writing process activity in which students draft and redraft in consultation with teachers or in peer-editing groups. 
This kind of activity may help students develop an understanding of story/narrative structures: The image sequences and the writing activities that arise from them could be used to introduce the students to various genres (e.g., narration, description) based on the ways visuals are organised. For example, using visuals that readily tell a story with either one or a number of possible plots, the teacher could work with the students to answer questions about who the main characters are; what they are doing; with whom, why, and how they are doing it; and so on. Following on from this, the students could try to organise the pictures into a sequence reflecting their own spoken and then written story-an activity that gives free rein to students' creativity and often has interesting results.

\section{Speaking and Listening}

The reading and writing activities described above could also be used in developing listening and speaking skills, as they provide ample opportunities for students to converse with the teacher and peers. After the reading readiness activities, for example, students could report back to the class, give short speeches, explain, or describe, with the rest of the class serving as listeners; the listening could be targeted and perhaps evaluated through follow-up worksheets.

In a testing format, images can be used in evaluating speaking skills: The evaluator could show students a picture from a story they have read and ask them to talk about it in the allotted time. This activity, which tests both production and understanding of the reading's content, could serve as part of a classwide evaluation to see which students understand a story's content and sequence best and, if required, as the basis for the allocation of grades.

\section{Vocabulary}

The interpretation of a visual in relation to any associated writing will necessarily involve encounters with new words. The students can immediately associate the words with a visual representation, which sets up cognitive associations that facilitate vocabulary learning. The use of visuals can also engender skills such as skimming and sight recognition of vocabulary. Skimming a reading and identifying words that relate to the visual as participants, processes, and circumstances can also stimulate students' prereading vocabulary development. Practice in pronunciation, both of single words and for fluency development, is a related possibility. 


\section{CONGLUSION}

Analysis of the interrelatedness of semiotic resources has the potential to conceptualize pedagogical approaches and should provide a foundation for research into how learners interact with multimodal material in the classroom. One area for exploration is students' and teachers' attitudes toward nonlinguistic modes. Tang (1991) comments on students' negative attitudes toward graphics such as charts and tables. This point applies equally to other visual modes, such as video and images: Do teachers need specific, systematic ways to help raise students' consciousness of the fact that alternative ways of communicating information and attitudes exist and that those alternatives can be interpreted in concert with language?

Teacher education has a role to play here. A number of graduate schools (e.g., the Teachers College off-campus MA in TESOL program in Tokyo, Japan) offer courses on how various visual media enrich the language learning experience and work in concert with other modes in both ESL and EFL contexts). I hope that this brief multimodal text analysis will stimulate further inquiry into teacher education that focuses how best to define and develop multimodal communicative competence.

\section{THE AUTHOR}

Terry Royce is director of the off-campus MA in TESOL program of Teachers College, Columbia University, in Japan. He serves on the Board of Directors of the Japan Association of Systemic Functional Linguistics. His research interests focus on the analysis of multimodality in economic and scientific discourse and relevant applications to educational practice.

\section{REFERENCES}

Arnheim, R. (1969). Visual thinking. Berkeley: University of California Press.

Arnheim, R. (1974). Art and visual perception. Berkeley: University of California Press. Arnheim, R. (1988). The power of the centre: A study of composition in the visual arts. Berkeley: University of California Press.

Barthes, R. (1967). Elements of semiology. London: Cape.

Barthes, R. (1977). Image, music, text. New York: Noonday Press.

Dondis, E. (1973). A primer of visual literacy. Cambridge, MA: MIT Press.

Dyer, G. (1982) Advertising as communication. London: Methuen.

Eco, U. (1976) A theory of semiotics. Bloomington: Indiana University Press

Fiske, J. (1982). Introduction to communication studies (2nd ed.). London: Routledge.

Gombrich, E. (1960). Art and illusion: A study of the psychology of pictorial representation. London: Phaidon Press.

Halliday, M. A. K. (1994). An introduction to functional grammar (2nd ed.). London: Edward Arnold.

Halliday, M. A. K., \& Hasan, R. (1976). Cohesion in English. London: Longman.

Halliday, M. A. K., \& Hasan, R. (1985). Language, context and text: Aspects of language in a social-semiotic perspective. Oxford: Oxford University Press. 
Kress, G. (2000). Multimodality: Challenges to thinking about language. TESOL Quarterly, 34, 337-340.

Kress, G., \& Hodge, R. (1979). Language as ideology. London: Routledge \& Kegan Paul.

Kress, G., \& van Leeuwen, T. (1996). Reading images: The grammar of visual design. London: Routledge.

Nielsen, A., Ford, S., \& Doherty, F. (1996). Science and life: Work, leisure, technology and the environment. Melbourne, Australia: Oxford University Press.

Nöth, W. (1995). Handbook of semiotics. Bloomington: Indiana University Press.

O'Toole, M. (1994). The language of displayed art. London: Leicester University Press.

Royce, T. (1998). A metafunctional view of intersemiosis in The Economist magazine: A framework for analysis. In T. D'Haen \& C. C. Barfoot (Eds.), Language and beyond (pp. 157-176). Amsterdam: Editions Rodopi.

Royce, T. (1999a). Synergy on the page: Exploring intersemiotic complementarity in page-based multimodal text. In N. Yamaguchi \& W. Bowche (Eds.), JASFL Occasional Papers, 1, 25-49.

Royce, T. (1999b). Visual-verbal intersemiotic complementarity in The Economist magazine. Unpublished doctoral dissertation, University of Reading, England.

Saint-Martin, F. (1987). Semiotics of visual language. Bloomington: Indiana University Press.

Tang, G. (1991). The role and value of graphic representation of knowledge structures in ESL learning: An ethnographic study. TESL Canada Journal, 9(1), 29-41.

Tufte, E. R. (1983). The visual display of quantitative information. Cheshire, CT: Graphics Press.

\section{FURTHER READING ON SYSTEMIC FUNCTIONAL LINGUISTICS}

Arnheim, R. (1992). To the rescue of art: Twenty-six essays. Berkeley: University of California Press.

Bloor, T., \& Bloor, M. (1995). The functional analysis of English: A Hallidayan approach. London: Edward Arnold.

Gombrich, E. (1982). The image and the eye: Further studies in the psychology of pictorial representation. London: Phaidon Press.

Halliday, M. A. K. (1978). Language as social semiotic. London: Edward Arnold.

Halliday, M. A. K. (1987). Language and the order of nature. In C. MacCabe, N. Fabb, D. Attridge, \& A. Durant (Eds.), The linguistics of writing: Arguments between language and literature (pp. 135-154). Manchester, England: Manchester University Press.

Halliday, M. A. K. (1991). The notion of context in language education. In T. Lê \& M. McCausland (Eds.), Language education: Interaction and development. Proceedings of the International Conference on Language Education (pp. 1-26). Launceston, Tasmania: University of Tasmania.

Halliday, M. A. K. (1992). How do you mean? In M. Davies \& L. Ravelli (Eds.), Advances in systemic linguistics: Recent theory and practice (pp. 20-35). London: Pinter.

Hasan, R. (1996). Ways of saying, ways of meaning: Selected papers of Ruqaiya Hasan (C. Cloran, D. Butt, \& G. Williams, Eds.). London: Cassell.

Panofsky, E. (1982). Meaning in the visual arts. Chicago: University of Chicago Press.

Royce, T. (2000, March). The visual and the verbal: An investigation of ideational intersemiotic complementarity in page-based science text. Paper presented at the collo- 
quium on Language, Media, and Science Education, American Association of Applied Linguistics conference, Vancouver, British Columbia, Canada.

Thompson, G. (1996). Introducing functional grammar. London: Edward Arnold. Uspensky, B. (1973). A poetics of composition. Berkeley: University of California Press.

\section{APPENDIX}

\section{Water Cycle Diagram and Text}

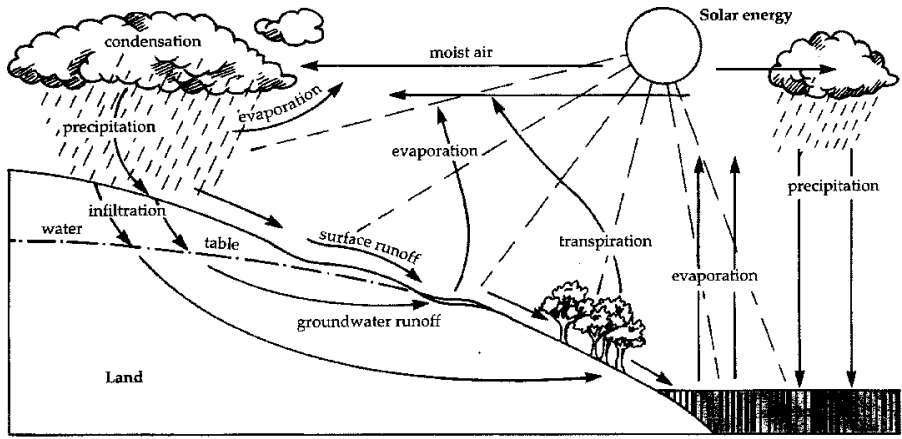

Figure 8.12 The water cycie

Australia is known for its low rainfall, especially in the inland. Water, therefore, should be considered precious and be managed carefully at all times.

To make better use of the water falling on the continent, dams are built to hold the water back. They can be:

- dams to supply large cities with water for both domestic and industrial use such as Eildon Reservoir for Melbourne and Warragamba Dam for Sydney;

- dams for diverting water away from flowing to the ocean so they flow inland for irrigation such as the Snowy Mountains Scheme - the water flows into the Murray and Murrumbidgee Rivers and irrigates vast areas;

- farm dams, which are very small but extremely important as they supply drinking water for animals and supplement tank water for household use on farms.

Some adverse effects of dams are these:

- Evaporation from the reservoir can be very high, especially in summer time.

- Siltation can occur in reservoirs. This doesn't allow the sill to be carried downstream during a flood and be deposited on the floodplains. Consequently the plains are deprived of this rich, fertile silt.

- Migratory fish can have their life cycle disturbed and they may disappear from the river.

- Fertile land, homes or places with heritage value such as Aboriginal sacred sites may be drowned during the formation of the dam.

\section{Necessity for better water management}

People are now able to control and use water more efficiently, but with this have come more problems. Some are:

- Overuse of irrigation, which together with removal of trees results in salination of the soil. This high salt level makes it impossible for plants to grow, so the soil becomes useless. This is a serious problem in parts of the Murray River Valley but has been partly remedied by drip irrigation.

- Taking too much underground water by putting down bores and pumping it out. This water is constantly being replenished by seepage from ground water. However, if it is taken too rapidly the supply may rum out as no-one knows how much artesian water there is. This could result in drying up of marshes and swamps, which are the home of many birds, fish and other water animals as well as water plants.

- Polluting of water by runoff of chemicals from factories and refineries. There are strict laws about the amount of discharge allowed, to protect the environment. Sometimes though, these laws are broken, either knowingly or unknowingly, and many aquatic organisms die. Many less developed countries do not have the same strict laws that Australia has and very serious pollution occurs.

From Science and Life: Work, Leisure, Technology and the Environment (pp. 191-193), by A. Nielsen, S. Ford, and F. Doherty, 1996, Melbourne, Australia: Oxford University Press. Copyright 2002 by Ann Nielsen. Reprinted with permission. 
1. Management of natural resources

2. Natural resources, both renewable and non-renewable, need to be conserved for use today and for future populations.

3. Let's first look at renewable resources.

4. We would expect that renewable resources would always be available, but if people continue to damage the earth it will not be able to continue producing these resources.

5. In some countries people are poisoning the land with pesticide residues and killing off trees with acid rain.

6. Air pollution levels of many major cities are frequently higher than is considered acceptable by health authorities.

7. Water as a renewable resource

8. The management of fresh water will be considered but there are many other renewable resources that can be investigated, such as timber, air, food and wool.

9. Figure 8.12 shows the water cycle but it doesn't show where water falls on the earth.

10. For example, desert areas get very little and irregular rainfall, and tropical rainforests get fairly constant heavy rains in the wet season.

11. Australia is known for its low rainfall, especially in the inland.

12. Water, therefore, should be considered precious and be managed carefully at all times.

13. To make better use of the water falling on the continent, dams are built to hold the water back.

14. They can be: dams to supply large cities with water for both domestic and industrial use such as Eildon reservoir for Melbourne and Warragamba dam for Sydney;

15. dams for diverting water away from flowing to the ocean so they flow inland for irrigation such as the Snowy Mountains Scheme-the water flows into the Murray and Murrumbidgee Rivers and irrigates vast areas;

16. farm dams, which are very small but extremely important as they supply drinking water for animals and supplement tank water for household use on farms.

17. Some adverse effects of dams are these: Evaporation from the reservoir can be very high, especially in summer time.

18. Siltation can occur in reservoirs.

19. This doesn't allow the silt to be carried downstream during a flood and be deposited on the flood plains.

20. Consequently the plains are deprived of this rich, fertile silt.

21. Migratory fish can have their life cycle disturbed and they may disappear from the river.

22. Fertile land, homes or places with heritage value such as Aboriginal sacred sites may be drowned during the formation of the dam.

23. Necessity for better water management

24. People are now able to control and use water more efficiently, but with this have come more problems.

25. Some are: Overuse of irrigation, which together with removal of trees results in salination of the soil.

26. This high salt level makes it impossible for plants to grow, so the soil becomes useless.

27. This is a serious problem in parts of the Murray River Valley but has been partly remedied by drip irrigation.

28. Taking too much underground water by putting down bores and pumping it out.

29. This water is constantly being replenished by seepage from ground water.

30. However, if it is taken too rapidly the supply may run out as no-one knows how much artesian water there is.

31. This could result in drying up of marshes and swamps, which are the home of many birds, fish and other water animals as well as water plants.

32. Polluting of water by runoff of chemicals from factories and refineries. 
33. There are strict laws about the amount of discharge allowed, to protect the environment.

34. Sometimes though, these laws are broken, either knowingly or unknowingly, and many aquatic organisms die.

35. Many less developed countries do not have the same strict laws that Australia has and very serious pollution occurs.

36. New South Wales has had a deterioration of its water quality in inland rivers as well as the ones near big cities like Sydney.

37. To help counteract this problem, schools all over NSW are getting involved in a program called Streamwatch to monitor water quality, and through government and community action they are trying to improve the water quality for themselves and for future generations.

38. Schools as far afield as Bombala in the south, Tweed Heads in the north and schools out west such as Wilcannia, Bourke, Brewarrina and Broken Hill are all involved in the Streamwatch program. 